\title{
Mundtlighed i danskfaget og dets læremidler
}

Af Lene Skov Illum og Dorthe Carlsen, UC SYD

Korrekt citering af denne artikel efter APA-systemet (American Psychological Association System, 7th Edition): Illum, L. S. \& Carlsen, D. (2020). Mundtlighed i danskfaget og dets læremidler. Learning Tech - Tidsskrift for læremidler, didaktik og teknologi, (8), 10-39. DOI 10.7146/lt.v\%vi\%i.120633 


\section{Abstract}

Mundtlighed er en central del af al undervisning, hvor læreren viser tilrette gennem samtale, men netop i modersmålsfaget er mundtlighed samtidig indhold. Eleven skal lære at ytre sig og lytte og indgå i mange forskellige mundtlige kommunikationssituationer. Man må derfor forvente, at læremidler til danskundervisningen giver et bud på, hvordan læreren kan undervise i mundtlighed. Samtidig tyder meget på, at mundtlighed ikke fylder meget som indhold i modersmålsundervisningen. I denne artikel fremstilles en læremiddelanalyse af to didaktiske læremidler. Analysen fokuserer på, hvordan og i hvilken udstrækning mundtlighed gøres til indhold i et af de mest anvendte læremidler til modersmålsundervisningen samt et temabaseret, præmieret læremiddel med særligt fokus på mundtlighed. Analysen munder ud i en vurdering af læremidlernes "potentielle læringspotentiale". Lytning anses for en integreret del af mundtligheden. Teorien operationaliseres i "Mundtlighedstrekanten", som bidrager med et metasprog om mundtligt sprog, der også ville kunne anvendes i lærerens fagdidaktiske planlægning og refleksion.

Orality is a central part of education, but orality is also content in L1. The student needs to learn how to speak and listen and to be part of different oral situations. Therefore, it would be expected that the teaching aids of L1 would suggest ways for the teacher to teach orality. But much indicates that orality does not play a substantial role as content in L1.

This article presents an analysis of two didactical learning resources. The focus is how and to which extent is orality made content in three of the most frequently used learning resources for L1, as well as a theme-based, prizewinning learning resource with a specific focus on orality. The analysis concludes in an assessment of the "potential learning-potential" of the learning resource. Listening is regarded as in integrated aspect of orality. The theory is operationalised in the "Triangle of Orality". 


\title{
Mundtlighed i danskfaget og dets læremidler
}

\author{
Indledning
}

I danskundervisningen skriver eleverne blogindlæg, eventyr og udkast til noveller. De læser en ungdomsroman, og de ser en film. Der foregår meget andet i danskundervisningen end samtale. Men omvendt er det svært at forestille sig en danskundervisning, der ikke i høj grad er præget af mundtlighed. Undervisning betyder "at vise til rette gennem samtalen" (von Oettingen, 2016, s. 73). Der er meget mundtlighed i undervisningen (Haugsted, 2000, s. 258), men er der også undervisning i mundtlighed?

\section{Mundtlighed i Fælles Mål}

Mundtlige kompetencer er en af de fire grundlæggende kompetencer (læse, lytte, skrive, tale), som eleverne skal undervises i på alle klassetrin i dansk. I danskfagets formålsparagraf står, at "Eleverne skal i faget dansk styrke deres beherskelse af sproget og fremme deres lyst til at bruge sproget personligt og alsidigt $i$ samspil med andre" (Undervisningsministeriet, 2019, s. 4), og i tre ud af fire kompetenceområder står elevens mundtlige sprog centralt i kompetencemålene efter 9. klasse. Under kompetenceområdet Kommunikation står, at eleverne efter 9. klasse skal kunne "deltage reflekteret i kommunikation i komplekse formelle og sociale situationer" (Undervisningsministeriet, 2019, s. 24), og under Fremstilling, at "Eleven kan udtrykke sig forståeligt, klart og varieret i skrift, tale, lyd og billede i en form, der passer til genre og situation" (Undervisningsministeriet, 2019, s. 20). Af kompetencemålene for Fortolkning fremgår, at det også kræver mundtlige kompetencer at undersøge, diskutere og forholde sig til æstetiske tekster (Undervisningsministeriet, 2019). Danskundervisningen skal sætte eleverne i stand til at kunne informere, samtale, diskutere, argumentere samt lytte og respondere på tekster i bred forstand og både i og om praktiske og æstetiske tekster. Dette er forudsætninger for at kunne deltage aktivt i skolens fag, i samfundslivet og privatlivet. 
Vi indgår aktuelt i en række mindre forskningsprojekter, hvor fagdidaktiske forskere, lærere, læreruddannere og lærerstuderende undersøger og eksperimenterer med forskellige aspekter af mundtlighed i modersmålsundervisningen inden for rammerne af Universitetsskolen (Skov, 2018; Carlsen \& Ipsen, 2019). Disse studier viser, at der arbejdes meget lidt systematisk og samtidig ensidigt med udvikling af elevernes mundtlige færdigheder. Det samme mønster ses i norske undersøgelser. De viser tillige, at når der arbejdes med mundtlige færdigheder, er det i høj grad elevfremlæggelser, som dominerer, dvs. undervisningen omfatter kun dele af de i læreplanen beskrevne mål (Svenkerud, 2013).

Den norske modersmålsdidaktiker Liv Aksnes påpeger, at man i Norge har såvel et skrivecenter som et læsecenter, men ikke noget mundtlighedscenter (Aksnes, 2016, s. 16). Noget lignende gælder i Danmark, hvor vi har et Nationalt Videncenter for Læsning, et Center for Læseforskning (KU) samt et stærkt skrivedidaktisk miljø på SDU. Også i Danmark efterlyses en egentlig mundtlighedsdidaktik (Kirkegaard, 2018; Høegh, 2017, 2018).

I nærværende projekt undersøges, hvordan og i hvilken udstrækning mundtlighed gøres til indhold i læremidler til modersmålsundervisningen. Læremidler betragtes som et didaktisk holdepunkt og en inspirationskilde i forhold til både fagligt indhold og undervisningsaktiviteter (Hodgson, Roenning, Skogvold \& Tomlinson, 2010, s. 87). Læremidler har to sider: intenderet brug og realiseret brug. Nærværende undersøgelse er en undersøgelse af læremidlernes intenderede brug og har derfor ikke udsigelseskraft i forhold til, hvad der faktisk foregår i undervisningen med disse læremidler. Det er imidlertid rimeligt at antage, at læremidlerne spiller en central rolle heri (Danmarks Evalueringsinstitut, 2012).

Genstandsfeltet for undersøgelsen er to didaktiske læremidler til danskundervisningen på mellemtrinnet. danskfaget.dk er et digitalt didaktisk læremiddel og er valgt som analyseobjekt, da det fremgår af en kvantitativ læremiddelundersøgelse, at netop dette læremiddel er et af de mest brugte og af lærere bedst vurderede (Bundsgaard, Buch \& Fougt, 2017). Læremidlet Ordet er dit er et temabaseret læremiddel om mundtlighed, som i 2017 modtog en andenplads ved uddelingen af Undervisningsministeriets Undervisningsmiddelprisen. I valg af læremidler har vi ikke været optagede af, at det ene læremiddel er bogbaseret og det andet digitalt. Undersøgelser tyder på, at der i klasserummet er en "blan- 
dingskultur", hvor bogbaserede og digitale læremidler anvendes side om side (Gilje, 2015, s. 37; Gilje, Ingulfsen, Dolonen, Furberg, Rasmussen, Kluge, Knain, Mørch, Naalsund \& Skarpas., 2016, s. 18; Skjelbred, 2019).

\section{Læremiddelanalyse}

Didaktiske læremidler er læremidler produceret med henblik på undervisning i et bestemt indhold i et bestemt fag (Hansen \& Skovmand, 2011, s. 19). Dagrun Skjelbred kalder sådanne læremidler for primære, intenderede skoletekster (Skjelbred, 2019, s. 22). Analyse og vurdering af et læremiddels "potentielle læringspotentiale" (Hansen \& Bundsgaard, 2011) er ikke kun forskningsmæssigt interessant. At vælge læremidler er en central pædagogisk og fagdidaktisk opgave for læreren, og derfor må læreren også kunne foretage kritiske analyser og vurderinger.

I vores analyser, der fremstilles her, foretages vurderingerne af de to læremidler ud fra eksplicitte forestillinger om, hvad mundtlighed i danskfaget er og kan være (jf. analysens teoretiske afsæt). Det er væsentligt at understrege, at analyser og vurderinger, som udtrykkes i denne artikel, ikke er analyser og vurderinger af læremidlerne i deres helhed, men alene et fokuseret nedslag på vurdering af behandlingen af mundtlighed som fagligt genstandsfelt i danskundervisningen.

Man kan anlægge forskellige perspektiver på, hvad kvalitet i læremidler er. I læremiddeltjek (Hansen \& Skovmand, 2011, s. 105-109) anlægges tre perspektiver: Læremidlet skal have værdi for eleven, dvs. at det skal være tilgængeligt, have en faglig og social progression, og det skal på differentierede måder invitere alle elever til at deltage i undervisningen. Desuden skal læremidlet støtte læreren i det pædagogiske og fagdidaktiske arbejde. Endelig skal det sigte mod samfundets legitime mål for undervisningen, som disse udtrykkes i gældende læreplaner (Hansen \& Skovmand, 2011, s. 60). Læremidlet understøtter gennem dets eget udtryk, gennem valg af indhold og gennem forslag til aktiviteter disse mål. Da vi i nærværende analyse og vurdering er særligt optagede af mundtlighed som indhold i danskundervisningen, fokuserer vi i vores analyser på forholdet mellem de mål for undervisningen, som ekspliciteres i læremidlet, de indholdsvalg, der er truffet, og de forslag til aktiviteter, som læremidlet præsenterer. 


\section{Hvad er mundtlighed?}

Mundtlighed defineres som: "en kommunikativ enhed, hvor kroppe og blikke og gestik hører med, og kommunikativ mening opstår situationelt: Talesproget fungerer i specifikke situationer med specifikke deltagere og specifikke formål og funktioner, og alle situationens kontekster bestemmer vores tolkning og betydningsforhandlinger hver gang" (Høegh, 2018, s. 31).

Definitionen bygger på et balanceret literacy-begreb, hvor literacy forstås som menneskets evne til at afkode, forstå og anvende tegn i den sociale praksis, hvori sprog indgår (Nationalt Videncenter for Læsning: Literacy $n r .12,2012)$. Dette literacybegreb bygger på tekstforståelse i bred forstand og forudsætter både sociale og kulturelle kompetencer samt kognitive og psykologiske processer (Blikstad-Balas, 2019). Inden for den kognitive literacyforskning er man optaget af, hvordan psykologiske evner gør os i stand til at bruge sprog for at skabe mening. Det gælder fx udvikling af ordforråd og hvilke strategier, vi tager i brug, når vi skal samhandle med tekst. Inden for sociokulturel teori er man optaget af brugen af tekster, altså hvad mennesker gør med sprog og tekster i forskellige situationer. Sprog og sprogbrug opfattes som en kommunikativ og social praksis.

James Paul Gee er optaget af, hvordan man i netop en skolekontekst bruger sprog og tekster på specielle måder. Gee tager ligeledes afsæt i en bred forståelse af literacy og inkluderer tillige de diskursfællesskaber, man er en del af, og hvordan disse fællesskaber bliver formet gennem deltagelse. Begrebet diskurs dækker både over måder, hvorpå man kan tale om verden, og måder at være i verden på. "Primærdiskurs" refererer til de sproglige diskurser og erfaringer, som tilegnes i hjemmet; "sekundærdiskurser" er de diskurser, man socialiseres ind i, fx i skolen (Gee, u.å.).

I skolen handler det om at få adgang til sekundærdiskurser, men undersøgelser viser, at mange elever i dag møder primærdiskurser i skolen (Blikstad-Balas, 2019, s. 90). Skolen bliver i stigende grad forbundet med elevernes individuelle tekstpraksisser og brugen af fagtekster og fagbegreber bliver mindre synlig (Blikstad-Balas, 2019, s. 90). Derfor er det nødvendigt, at læremidlerne anvender for faget relevante tekster og sprog (Blikstad-Balas, 2019, s. 76). Samtaler om og med tekster bør ske i en sekundærdiskurs og gøres tilgængelig for alle. Lærerens - og læremidlernes - opgave er derfor at gøre teksterne og diskurser- 
ne synlige, så eleverne kan få øje på og "erobre" det faglige indhold (Blikstad-Balas, 2019, s. 110).

\section{Lytning}

Lytning er en integreret del af mundtligheden (Høegh, 2018), og god lytteforståelse er en forudsætning for at kunne deltage aktivt i mundtlighedssituationer. Men lytning er ikke integreret i skolens og danskfagets mundtlighed; lytning er didaktiktisk-ikke-eksisterende (Adelmann, 2012) og "en blind plet som undervisningsemne og læringsstrategi for eleverne, såvel som en blind plet for lærerne i egen forberedelse, undervisning og evaluering" (Høegh, 2020).

Lyttebegrebet er omfattende og har mange betydningsnuancer (Otnes, 2016). I denne kontekst fokuseres på lytning i en social betydning forstået som at 'lytte til' noget, fx lytte koncentreret på en oplæsning eller en forelæsning og at 'lytte opmærksomt og empatisk' i dialog med andre, fx en samtale. I relation til ovenstående literacy-definition baseres forståelsen af lytning på en kombination af en sociokulturel og kognitiv tilgang, idet lytning både har et kognitivt, intrapersonelt perspektiv og et sociokulturelt, interpersonelt perspektiv. Lytning indbefatter både sociale og sproglige processer og handlinger. De faglige begreber, der er i spil i denne sammenhæng, er begreber som lyttehandlinger, lyttekompetence, lytteformål, lytteforståelse, lyttestrategier, lytteadfærd og respons.

Lytning ligger som en underliggende præmis i det meste af al undervisning. I løbet af en skoledag sættes elever i forskellige lyttesituationer, hvor de både skal lytte for at lære et fag og lytte interaktionelt og empatisk. De skal fx lytte til lærerens faglige oplæg og mundtlige instruktioner, og de skal lytte til hinanden, når de fx arbejder i grupper eller deltager i den fælles klasserumssamtale. De forskellige lyttesituationer kræver forskellige formål, lyttestrategier og lytteadfærd. Eleverne skal derfor lære at spørge om, hvad formålet med lyttehandlingen er, hvilken lytteindsats ogforståelsesbearbejdning, det kræver, og endelig må de overveje en relevant lytteadfoerd (Høegh, 2018). Undervisning $i$ lytning bør være en integreret del af den danskfaglige undervisning i mundtlighed.

\section{Mundtlighedstrekant}

Vores forståelse af mundtlighed operationaliseres i mundtlighedstrekanten, Figur 1. Mundtlighedstrekanten er inspireret af 
teksttrekanten, der er udviklet til skrivevejledning og tekstarbejde i skriftlige verbalsproglige tekster (Dysthe, Hertzberg \& Hoel, 2001, s. 43). Teksttrekanten er i forskellige sammenhænge omkalfatret ud fra forskellige teoretiske perspektiver på tekster, fx har Nikolaj Elf udarbejdet en semiotisk teksttrekant (Elf, 2017, s. 179).

Figur 1.

Mundtlighedstrekant.

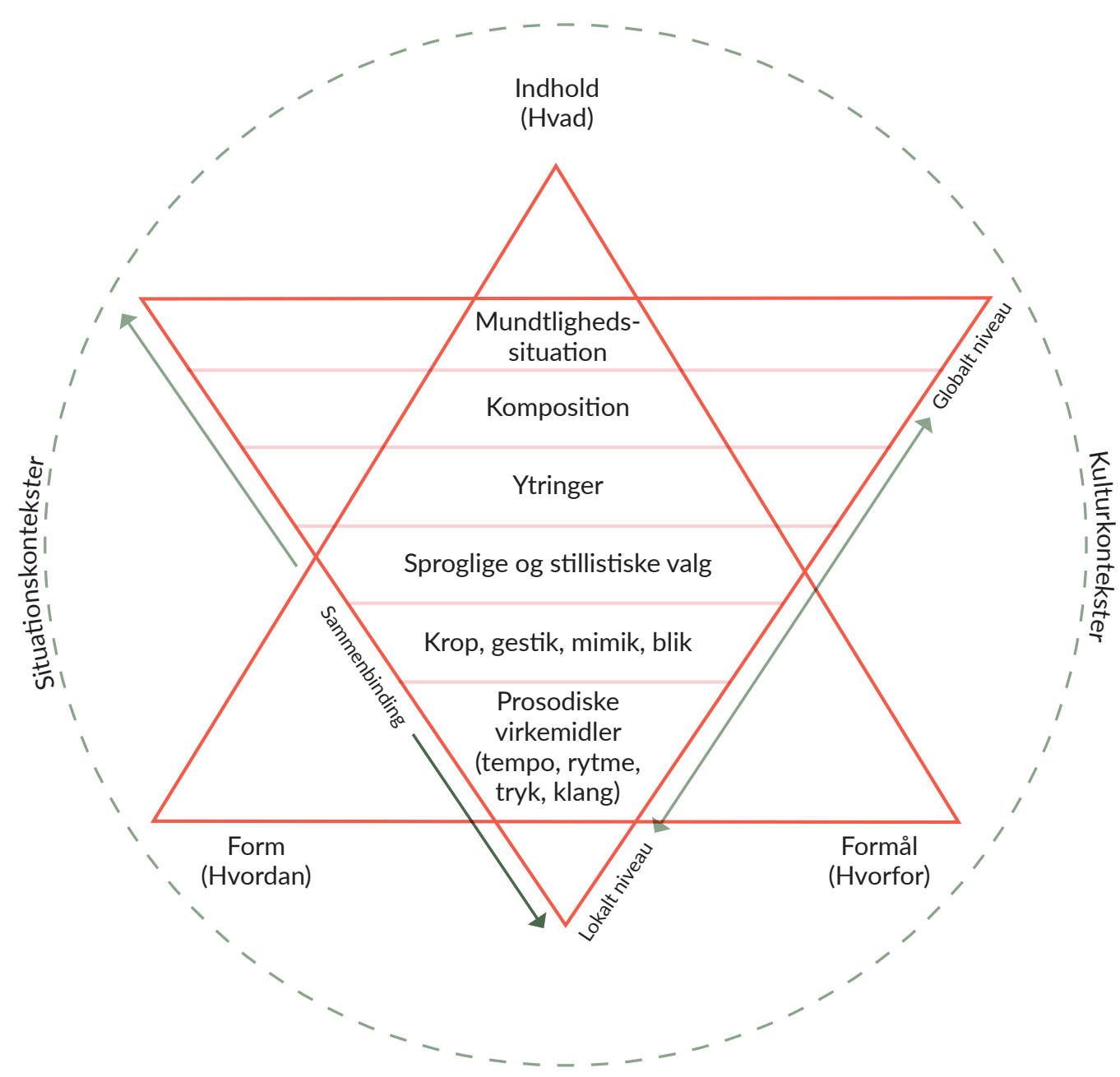

Mundtlighedstrekanten, som stadig er under udvikling, tager afsæt i et udvidet tekstbegreb, som også rummer talehandlinger. Thomas Illum Hansen fremstiller i Dansk (2015) med afsæt i Ole Togebys teori om verbalsproglige tekster og genrer (2014) et bud på en fagdidaktisk teksttypologi. Hansen overskrider Togebys skelnen mellem talehandlinger og teksthandlinger, bl.a. fordi de 
begge indgår som centrale sproghandlinger, der udgør danskfagets genstandsfelt (Hansen, 2015, s. 33). Talehandlinger forstås på linje med ovenstående definition af mundtlighed som "dialogiske handlinger, hvor man anvender relativt få ord til at udtrykke hensigter og opnå mål i forhold til en anden part i kommunikationen" (Hansen, 2015, s. 35). Hansen argumenterer for, at man med det udvidede tekstbegreb kan udvide talehandlinger til at omfatte "alle flygtige og simultane tegnhandlinger, der bruges til at udtrykke hensigter og interagere i en kommunikationssituation" (Hansen, 2015, s. 40).

Den yderste trekant i modellen viser, at mundtlighedstrekanten bygger på en handlingsorienteret, pragmatisk tekst- og sprogforståelse, hvor forholdet mellem indhold, form og formål er centralt. Alle ytringer består af et formål, en indholdsside og en formside (Ongstad, 2004). Betydning skabes således i samspillet mellem, hvem siger hvad til hvem, hvordan, hvorfor og i hvilken situation. Den omsluttende cirkel viser, at tekster skabes i sociale rum (situations- og kulturkontekster), som også virker ind på den mundtlige tekst.

Som tidligere nævnt bygger mundtlighedstrekanten på teksttrekanten (Dysthe, Hertzberg \& Hoel, 2001). I den inderste trekant skelnes mellem de forskellige dele af den mundtlige tekst. At tale indebærer, at man er i stand til at sammenholde forskellige dele (den inderste trekant) i en form for orden. Delene er byggestenene i den mundtlige kommunikation og viser, hvilke niveauer, der er i den mundtlige tekst. De øverste lag hører til på globalt niveau, dvs. et mere overordnet niveau i teksten (viden om mundtlige situationer, tekstopbygning, ytringer), mens de nederste lag hører til på lokalt niveau, et mere konkret niveau (sproglige og stillistiske valg, krop og mimik, prosodiske virkemidler). De nederste niveauer i trekanten er også kendetegnet ved at være flygtige og simultane tegnhandlinger, som overvejende vil være kropsligt funderet. Niveauerne har hver deres faglige udfordringer alt efter kommunikationssituationen, og vil altid indgå i et samspil. I en undervisningssituation er det dog muligt at fokusere på enkelte dele i trekanten. Som redegjort for ovenstående er lytning en integreret del af mundtligheden og indgår derfor ligeledes på alle niveauer i mundtlighedstrekanten. 


\section{Hvad er indhold i danskfagets mundtlig- hedsundervisning?}

Mundtlighedstrekanten er en generisk model, der viser forskellige niveauer ${ }^{1}$ af en mundtlig tekst, og som analyseoptik kan mundtlighedstrekanten være med til at synliggøre, hvilke niveauer i en mundtlig tekst, der gøres til genstand for undervisning. Men mundtlighedstrekanten viser ikke, hvad det didaktisk set vil sige at gøre mundtlighed til indhold i danskundervisningen. Dertil er brug for didaktiske indholdsmodeller, som fx Thomas Illum Hansens indholdsmodel:

Figur 2.

Indholdsmodel (Hansen, 2012, s. 199).

1. Erkendelsens subjekter

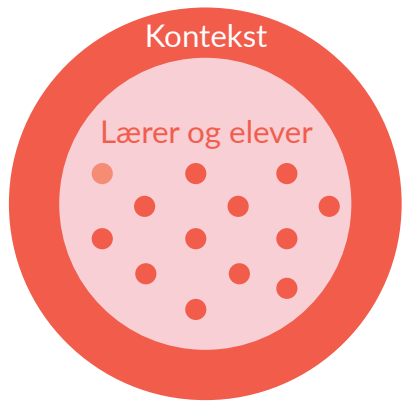

2. Erkendelsens mediering

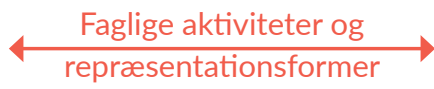

3. Erkendelsens objekter

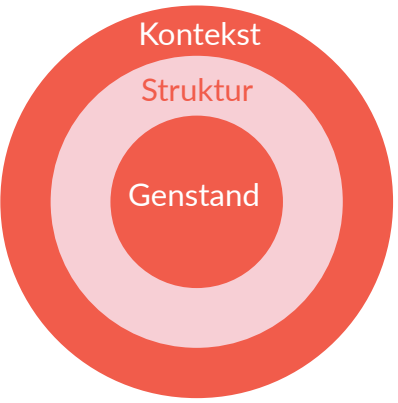

Modellen viser, at undervisningsindhold kan være elevernes egne oplevelser og deres samarbejde (erkendelsens subjekter), fx hvis læreren underviser eleverne i betydningen af et dialogisk klasserum for deres læringsudbytte. Det kan også være faglige aktiviteter som undervisning i retorik (erkendelsens mediering), og det kan være mundtlige tekster som en fortælling, en tale eller en diskussion, der er eksempler på danskfagets faglige genstande - tekster i kontekst.

Modellen udpeger ikke, hvilke tekster der bør undervises i i danskfaget. Det er lærerens - eller læremidlets - fagdidaktiske opgave og ansvar.

1 "Niveau" skal ikke forstås som et over- og underordningsforhold, da alle niveauer eller lag er gensidigt afhængige og integreres i mundtlige tekster. 


\section{Ordet er dit}

\section{Karakteristik}

Ordet er dit. Fokus på mundtlighed af Pernille Hargbøl Madsen (2016) er et analogt didaktisk læremiddel, der beskæftiger sig med danskfagets mundtlige tekster. Materialet findes til 3.- 4.-', 5.- 6.- og 7.-8. klasse. Materialerne er bygget ensartet op: Kapitel 1 handler om stemme og krop, hvor 4.-5. klasse adskiller sig ved også at omhandle lytning, kapitel 2 handler om fortælling, kapitel 3 oplæsning, kapitel 4 , samtalen og kapitel 5 handler om fremlæggelse.

I det følgende analyseres Ordet er dit. Fokus på mundtlighed i 5.-6. klasse. Denne del af serien adskiller sig ved at have eksplicit fokus på lytning og introducerer således et på mange måder overset område i danskundervisningen og i læremidlerne. Det er derfor interessant at undersøge, hvordan særligt lytning behandles som fagligt stof i læremidlet.

Lærervejledningerne består af en kort gennemgang af materialets teoriramme. Det pointeres, at der nok undervises for lidt i mundtlighed, og at eleverne skal have værktøjer til at udvikle deres mundtlige kompetencer (s. 6). Når der undervises $i$ mundtlighed, rejser der sig vigtige spørgsmål, som læremidlet hævder at give konkrete svar på, fx hvordan udvælges indholdet $\mathrm{i}$ undervisningen?, hvilke mundtlige genrer skal der undervises i? og er talesproget en personlig sag? (s. 7).

Sprogbrug opfattes som "en kommunikativ handling” (s. 10), og det pointeres, at når der arbejdes med at producere mundtlige tekster, kan der arbejdes med "på den ene side tekstens indhold, dens typiske genretræk, hensigt og kontekst, og på den anden

side tekstens form og det, der er særligt for dens mundtlige tekst: intonation, artikulation, tempo, styrke, toneleje, pauser, ordvalg, struktur, sproglig stil m.m. “(s. 11).

Derudover indeholder vejledningen en kapitel-for-kapitel-vejledning samt supplerende arbejdsark, og på forlagets hjemmeside findes ekstramateriale i form af lydfiler og film. Materialet er tilrettelagt ud fra Fælles Mål og opstiller læringsmål for hvert kapitel, ligesom der i alle kapitler arbejdes med respons og evaluering.

\section{Analyse}

I det følgende analyseres kapitel 1 “Tal og Lyt”, idet det som sagt adskiller sig ved at omhandle lytning. Lytning er en del af kapitlets indledende læringsmål og bliver italesat som "at lytte aktivt" 
(s. 6). De øvrige læringsmål omhandler kropssprog, vejrtrækning og stemmebrug, og størstedelen af kapitlet har fokus på netop disse læringsmål.

Under overskriften "Slå ørerne ud" behandles lytning ganske kort. Der skelnes mellem 'at høre' og 'at lytte'. At høre er en af vore sanser, altså et fysiologisk fænomen, som "virker uden at vi gør noget for det" (s. 16). At lytte kræver derimod en aktiv handling: "Når du lytter, kan du gøre noget aktivt" (s. 16), men det defineres ikke nærmere, hvad "noget aktivt" er. Til gengæld understreges det, at lytning er en evne, man må træne, fordi det "kan altså gøre det nemmere for dig at lære." (s. 16). Lytning er altså en læringstrategi.

I opgave a, "Find fejl", pointeres indledningsvist, at det "kan være en stor hjælp at vide, hvad man lytter efter. Det kaldes at lytte fokuseret." (s. 16). Opgaven går ud på at lytte efter fejl i en oplæsning af en fiktionstekst (det kan fx være grammatiske fejl, forkerte ord eller navne). Bagefter skal eleverne tale om, hvorvidt det var nemt eller svært at finde fejlene, og om de lyttede anderledes, end de plejer (opgave b, s. 16). Eleverne bliver ikke introduceret for begreber som lytteformål, lytteforståelse eller for faglige lyttestrategier. I lærervejledningen står, at eleverne skal kende til flere måder at lytte på, fx: at lytte efter informationer, at lytte kritisk, at lytte empatisk og at lytte med hele kroppen. Det er svært at sige, hvad en opgave som at lytte efter fejl i en fiktionstekst skal klæde eleverne på til at kunne, og det er ikke en disciplin eleverne præsenteres for senere i materialet. I opgave c "Fortæl om din dag" (s. 17) skal eleverne lytte uinteresseret til en talers hverdagsfortælling. I lærervejledningen står, at lytning foregår rent kognitivt ("ligesom læsning") (s. 19), men i denne opgave er det sociokulturelle, interpersonelle perspektiv også i spil, og opgavens ikke-formulerede formål er netop, at eleverne skal blive bevidste om deres rolle som tilhørere i forhold til krop, gestik, blik, respons etc. Her ville et fagbegreb som lytteadfærd være relevant at introducere for eleverne. Opgaven afsluttes med en uformel samtale mellem eleverne om, hvordan man lytter uinteresseret. I en reel lyttesituation, hvor eleverne faktisk skal lytte interesseret, vil lytteformålet være dobbelt, idet de både skal fastholde det faglige fokus og samtidig være i stand til på baggrund af egne meninger og holdninger at forstå, interessere sig for og respektere andres perspektiver. Dette aspekt ville ligeledes være relevant at udfolde for eleverne. Eleverne præsenteres ikke for forskellene i de to lyttehandlinger i opgave a og b (at lytte til en 
oplæsning (fiktion) og at lytte til en hverdagsfortælling). Faglige begreber som lytteformål, lytteforståelse, lyttestrategier, lytteadfærd og respons kommer ikke i spil, og eleverne præsenteres ikke eksplicit for lyttestrategier, hverken kognitive eller interaktionelle. I opgave d "Tal om gode lytteråd" skal eleverne give gode lytteråd, og opgaven opsamles i fire generelle lytteråd (s. 18). Rådene dækker over en blanding af kognitive og interaktionelle processer, fx i lytteråd 1, hvor eleverne skal lytte opmærksomt (en kognitiv proces) og samtidig kigge på den, der taler (en interaktionel proces). Begge dele er i øvrigt afhængige af selve lyttehandlingen og lytteformålet.

Kapitlet afrundes med en evaluering, der ikke direkte inddrager lytning, men har et punkt der hedder: "Hvorfor er det vigtigt at være god til at lytte?". Eleverne bliver ikke evalueret i deres viden om fx lytteformål og lyttestrategier.

I lærervejledningen under supplerende idéer foreslås, at eleverne formidler et valgfrit emne med det formål at lytte aktivt til hinandens fremlæggelser. "For at styrke og træne lyttekompetencen anbefales det, at en gruppe får til opgave at gengive, hvad de har forstået" (s. 22). Men igen er der ingen eksplicit undervisning i, hvad lyttehandlingen kræver: hvad vil det sige at lytte efter information, og hvilken lytteindsats, forståelsesbearbejdning og lytteadfærd kræves?

Lytning som fagligt stof behandles ganske overfladisk i resten af materialet. Eleverne bliver undervejs bedt om at lytte til fx oplæsninger, livsfortællinger, fremlæggelser eller andres argumenter, og undervejs i de øvrige forløb i elevmaterialet bliver eleverne mindet om at bruge lytterådene, men der er ingen differentiering ift. det faglige stof (indhold) og formålet med at lytte. I lærervejledningen står, at eleverne skal lære at lytte på flere måder, fx lytte efter informationer, lytte kritisk eller empatisk, men læreren stilladseres ikke i de forskellige lytteformål eller gives forslag til, hvordan arbejdet kan gribes an, når der fx står, at det kan være nødvendigt at skabe mere formaliserede rum for lytning og skabe “øget bevidsthed om lytning gennem øvelser og aktiviteter (s. 19). Der er ikke meget i lærervejledningen eller elevmaterialet, der understøtter disse formål, eller klæder hverken læreren eller eleven på til arbejdet.

Det mundtlige sprog er flygtigt, og i lærervejledningen foreslås det videre, at man kan optage elevernes mundtlige tekster som et værktøj til læring (s. 17). Her gives dog ingen vejledning til læreren (eller eleverne) i, hvordan sådan et arbejde kan gribes 
an. Skal eleverne transkribere teksterne?, hvordan gøres det?, og hvordan skal de tale om deres mundtlige tekster? (Høegh, 2018)

\section{Vurdering}

Ordet er dit fremstår både som undervisning i og med mundtlighed. Der er rigtig mange tale- og lytteaktiviteter, hvor eleverne skal lytte til, tale om, drøfte, diskutere etc. (undervisning med), men der er ikke eksplicit undervisning $i$, hvad der fx kendetegner en diskussion i forhold til fx at "tale om" eller "drøfte", ligesom der ikke er eksplicit undervisning i de forskellige lyt-til-opgaver. Materialet er i høj grad også undervisning $i$ mundtlighed, hvor mundtligheden gøres til indhold i undervisningen, og eleverne præsenteres for analyseredskaber til forskellige mundtlige genrer.

Materialet har fokus på lytning, men selvom det ekspliciteres, at lytning skal trænes, og at det er en vigtig læringsstrategi, bliver der ikke introduceret mange konkrete fagbegreber eller fulgt op på det i de øvrige kapitler.

Med udgangspunkt i mundtlighedstrekanten kan man sige, at materialet i de enkeltstående kapitler kommer omkring de forskellige niveauer i den inderste trekant. Der er fokus fx på sprogets dele, sprogets rytme, kropssprog og lytning. Der inddrages flere mundtlighedshandlinger, fx fortælle (med det formål at underholde og engagere), informere (med det formål at formidle) og påvirke (med det formål at argumentere) - jf. den yderste trekant - men de enkelte elementer forbindes ikke i en integreret mundtlighedsdidaktik, hvor indhold, formål og form går hånd i hånd. Når eleverne skal fremlægge et emne om fx "Sundhed" eller "Slankekure", er formålet ikke kundskabsudvikling inden for danskfaget, men ren form, altså hvordan bygges en fremlæggelse op med udgangspunkt i det retoriske pentagram, og hvordan kan emnet formidles. Efter hvert kapitel bliver eleverne bedt om at reflektere over, hvad de har lært, og vurdere deres egen læring. Her er det op til læreren at sørge for, at dette kommer til at foregå inden for en sekundærdiskurs, hvor eleverne bruger fagsprog til at reflektere, fx i forhold til lytning, hvor begreber som lytteformål, lyttestrategier og lytteadfærd er relevante.

De mundtlighedssituationer, som eleverne møder i materialet, er de samme, som de møder i mange andre læremidler (primært oplæsning, fortælling, fremlæggelse, argumentation), og eleverne og lærerne bliver ikke præsenteret for mere udforskende mundtlighedssituationer med det formål at udforske, 
analysere, tolke og reflektere over danskfaglige problemstillinger. Læremidlet bevæger sig ofte inden for en primærdiskurs, fx når eleverne i kapitlet "Samtale og debat" skal blive enige om, hvilken menu der skal serveres på hytteturen, eller skal argumentere for, at de ikke skal rydde op på værelset. Det kan virke motiverende for eleverne, da undervisningen tager udgangspunkt i deres hverdagserfaringer, men det betyder, at eleverne ikke præsenteres for skolens sekundærdiskurs i forhold til danskfagets indhold. Selvom materialet indledningsvist pointerer, at undervisning $i$ mundtlighed også indebærer valg af indhold i undervisningen, er det ikke et område, der tematiseres i læremidlet. Undervisning i mundtlighed handler ikke kun om at "sige noget", men også "hvad taler vi om" (jf. Høegh, 2018). Skolens sekundærdiskurs træder frem i læremidlet, når mundtlighed som faglig aktivitet gøres til indhold i undervisningen, $\mathrm{fx}$ i arbejdet med det retoriske pentagram og argumentationsmodellen.

Materialet fremstår overordnet som et selvstændigt kursusforløb i mundtlighed. Risikoen er, at eleverne og lærerne ikke integrerer viden om mundtlighed i den daglige danskundervisning, selvom materialets eksplicitte mål netop er at "vise hvordan denne [den mundtlige dimension] kan prioriteres i den daglige undervisning" (Lærervejledning, s. 4). Mundtlighed risikerer på den måde at blive et appendiks til den 'rigtige' danskundervisning. 
Figur 3.

Analyse af Ordet er dit.

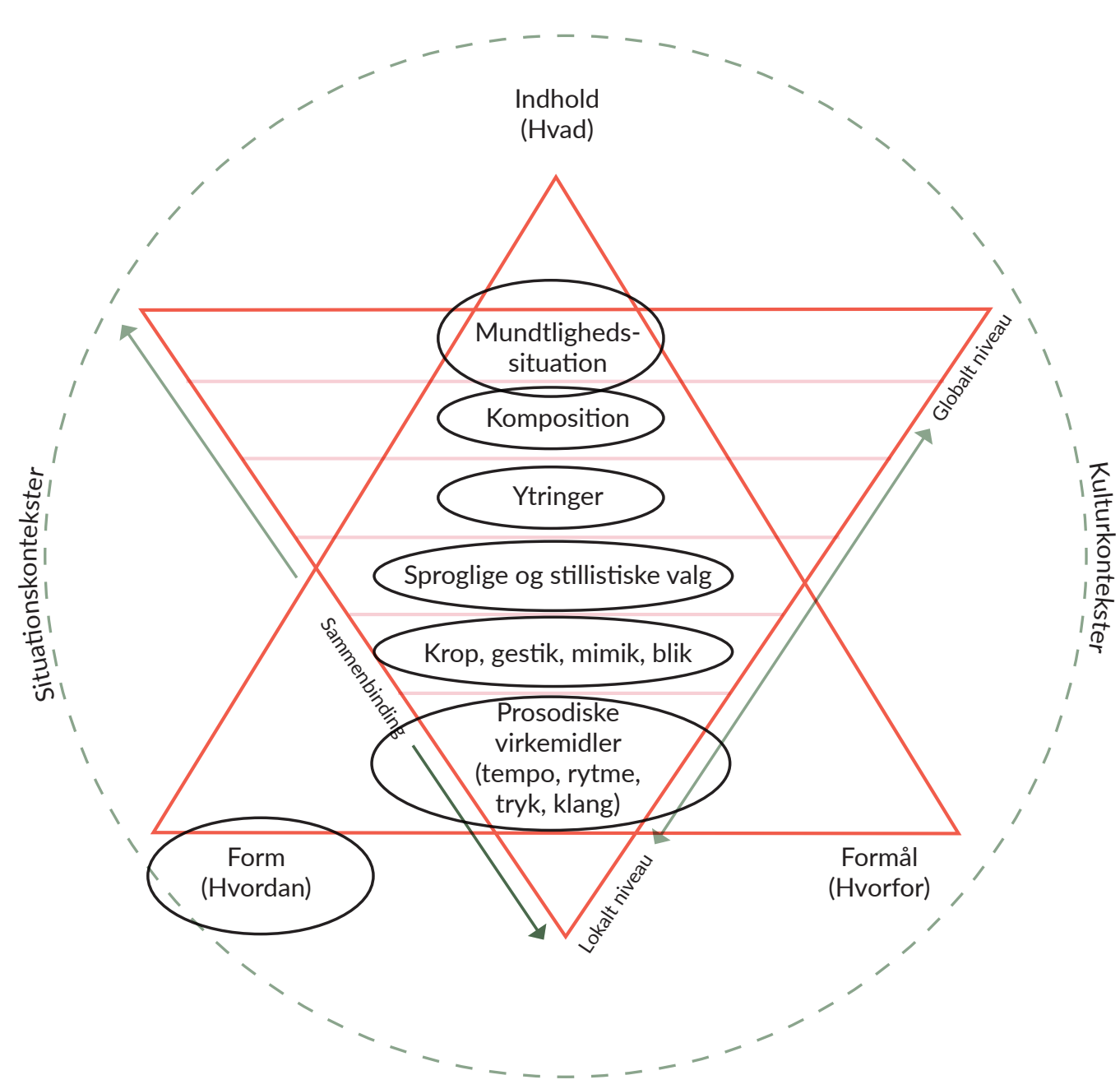

Modellen viser, at læremidlets fokus i høj grad ligger på den inderste trekant (sproglige og stilistiske virkemidler, krop, gestik, mimik, prosodi og lytning) med særlig vægt på form, altså hvordan skal mundtlighedshandlingen formidles.

\section{Danskfaget.dk}

\section{Karakteristik}

Danskfaget.dk (4.-6. klasse) er et didaktisk, digitalt læremiddel. Af introduktionen fremgår, at læremidlet indeholder 239 tekster, 765 aktiviteter og 1413 medielinks. Desuden er der 447 videoer, 37 lydklip og 298 e-tekster. Der er 76 forløb (opbygget 
efter Fælles Mål), årsplaner til dansk i 4., 5. og 6. klasse ${ }^{2}$. Det vil sige, at der er tale om et ganske omfangsrigt læremiddel - som løbende udvides. Af præsentationen af læremidlet fremgår, at "Danskfaget er et komplet undervisningsmateriale, der dækker Undervisningsministeriets krav til danskundervisningen på mellemtrinnet" (Jensen, u.å.b). Som nævnt er det et kvalitetskriterium for et læremiddel, at det sigter mod samfundets legitime mål for undervisningen således som disse udtrykkes i den gældende læreplan. Portalen er organiseret omkring fire hovedpunkter: Forløb, Emner, Ressourcer og Aktiviteter. Under menupunktet "Forløb" er undervisningsforløb og forslag til årsplaner.

Redaktørerne gør opmærksom på, at læreren må "supplere forløbene med individuel læsning og løsning af eksterne træningsopgaver, læseprøver og retskrivningsprøver” (Jensen, u.å.b). Denne beskrivelse er med til at understrege, at der er tale om et komplet undervisningsmateriale.

"Emner" er "en samling fagtekster inden for danskfagets kerneområder" (Jensen, u.å.b). Teksterne er inddelt i Faglitteratur, Skønlitteratur, Forfattere og perioder, Sprog, Medier og Retskrivning. Systematikken bag inddelingen er ikke ekspliciteret - og stemmer ikke overens med fx kompetenceområderne i Fælles Mål dansk (Undervisningsministeriet, 2019), der er Læsning, Fremstilling, Fortolkning og Kommunikation. Til emnet sprog hører "Læsning", "Skrivning", "Sprogbrug", "Nordens sprog", "Teksttyper", "Litterær læsning" og "Mundtlighed", hvoraf emnet "Mundtlighed" gøres til genstand for nærmere analyse nedenstående.

Menupunktet "Ressourcer" er kun synligt for læreren og er redskaber, der henvender sig til læreren, fx modeltekster, skriveskabeloner og aktantmodellen. Under "Ressourcer" er også en lærervejledning, der består af læseguides, introduktion til de tværgående temaer i Fælles Mål samt en uddybende tekst om portalen. I teksten "Danskfaget" bestemmes faget som et kommunikationsfag, hvor eleverne skal arbejde med tekster ud fra det udvidede tekstbegreb. Videre hedder det: 
Danskfaget er et kommunikationsfag, og kommunikationen skal være autentisk. Elevernes produktioner er ikke til læreren, men til verden. Når eleverne oplever, at de kommunikerer med en autentisk modtager, er de en del af det demokratiske samfund, og de vil opleve kommunikationen som værdifuld. Det digitale giver i særdeleshed mulighed for at sprænge skolens traditionelle rammer, hvor læreren som regel er modtager for enhver elevproduktion.

(https://portals.clio.me/dk/dansk/4-6/ressourcer/laerervejledning/ om-portalen/danskfaget/)

Danskfagets dannelsessigte knyttes tæt til udviklingen af elevernes literacy-kompetencer: "Inden for literacy-begrebet ligger danskfagets dannelsesdimension også. I mødet med såvel fag- og skønlitteratur og andre æstetiske tekster giver vi på Danskfaget mulighed for at skabe en kompetenceorienteret danskundervisning" (https://portals.clio.me/dk/dansk/4-6/ressourcer/laerervejledning/om-portalen/danskfaget/). Udgangspunktet for undervisningen er elevernes umiddelbare erfaringsverden, som det hedder. Karakteristikken af danskfaget rundes af med en understregning af, at eleverne skal opleve, at "skole og fritid, både i forhold til det indholdsmæssige og det digitale smelter sammen og giver mening" (https://portals.clio.me/dk/dansk/4-6/ressourcer/laerervejledning/om-portalen/danskfaget/).

Menupunktet "Aktiviteter" rummer en lang række varierede aktiviteter - fra at oprette en læsekontrakt til tegnsætningsøvelser. Aktiviteterne er inddelt i typer, fx "Billeder" og "Læsetræning". Under "Mundtlighed" er 19 aktiviteter à 30-135 minutters varighed. De tre første aktiviteter fremdrages her som eksempler på, hvordan der i læremidlet arbejdes med mundtlighed. I den første aktivitet skal eleverne under overskriften "Det offentlige privatliv" læse om det private rum, det semi-offentlige rum og det offentlige rum og efterfølgende i en selvkorrigerende drag-and-drop øvelse placere en række steder som "Mit værelse", "Dagligstuen", "Instagram" og "Facebook" i de tre rum (Jensen, u.å.c). I den næste aktivitet skal eleverne se, høre og omskrive dronningens nytårstale fra 2018 (Jensen, u.å.d). Endelig skal ele- 
verne i den tredje aktivitet lave en diskussionscirkel, hvori de diskuterer, om de bedst kan lide episke eller lyriske digte (Jensen, u.å.e). I nedenstående analyse af aktivitetstyper vendes tilbage til disse tre eksempler.

Indholdet til portalen er forfattet af mange forskellige forfattere. Af samme grund må det understreges, at analyse, karakteristik og vurdering alene vedrører de omtalte eksempler og udvalgte dele af læremidlet.

\section{Analyse}

I alle portalens undervisningsforløb indgår aktiviteter, der kræver elevernes brug af det mundtlige sprog. Eleverne skal snakke om, diskutere, fremlægge og lytte til - undervisning med mundtlighed. I det følgende undersøges nærmere eksempler på undervisning $i$ mundtlighed. Analysen består af tre nedslag: $\mathrm{i}$ ) en analyse af eksempler på aktivitetstypen mundtlighed, ii) en eksplorativ undersøgelse af, hvilke mundtlige tekster, der gøres til genstand for undervisning og hvordan, og iii) en analyse af det faglige emne mundtlighed.

\section{i. Aktivitetstyper}

Den første aktivitet, "Det offentlige privatliv" (Jensen, u.å.c), er et eksempel på, at kommunikationssituationer gøres til genstand for undervisning. Med internettet udvides en række kommunikative dimensioner. Det kan både bruges til privat og offentlig kommunikation, en-til-en, nogle-til-nogle, en-til-mange og mange-til-en. Niels Ole Finnemann fremhæver internettets potentialer som medie for både offentlig og privat kommunikation som en central egenskab (Finnemann, 2005, s. 142), men det er også en udfordring (Hansen, 2015, s. 40; Bundsgaard, 2008, 2017). Aktiviteten giver eleverne mulighed for at lære om forandrede kommunikationssituationer - og dermed, jf. Indholdsmodellen (Hansen, 2012, s. 199 - se side 11) om især teksters kontekster og betydningen af forholdet mellem tekst og kontekst. At kunne kende skelne mellem privat, semi-offentlig og offentlig kommunikation er undervisning i mundtlighed $\mathrm{i}$ den forstand, at det er undervisning i især mundtlighedstrekantens globale niveauer. Formålet med aktiviteten fremgår af læringsmålene, der eksplicit knytter an til færdighedsmålet "Eleven kan vurdere konsekvensen af ytringer på internettet" (Undervisningsministeriet, 2019, s. 15) og vidensmålet "Eleven har viden om muligheder og faldgruber for kommunikation på 
internettet" (Undervisningsministeriet, 2019, s. 15). Dvs. at der sigtes på udvikling af elevens kommunikationskritiske kompetencer. Aktiviteten "Dronningens nytårstale" (Jensen, u.å.d) har læringsmål som "Jeg kan vurdere talerens måde at fremføre sin tale på" og "Jeg kan eksperimentere med formen på en tale". Eleverne introduceres til tre forskellige taletyper (den politiske tale, lejlighedstalen og forsvarstalen) og til retoriske virkemidler som tempo og kropssprog. Derefter skal eleverne analysere dronningens nytårstale (2018) ved i to kolonner at notere i) hvad talen handler om og ii) stemme, tempo og kropssprog. Sammen med en makker skal eleverne derefter diskutere, om talen indeholder relevante emner, og om dronningens måde at fremføre talen på er passende. Endelig skal eleverne vælge en del af talen, som de skal omskrive til deres eget sprogbrug samt fremføre med brug af varieret tempo og mens de laver fagter. Denne fremførelse skal eleverne optage.

Med mundtlighedstrekanten som optik får man øje på, at aktiviteten fokuserer på sammenhængen mellem form og indhold i en lejlighedstale - om end på et elementært niveau, hvor de fleste elever nok vil opdage, at det er uhensigtsmæssigt at fægte alt for meget med arme og ben, mens man taler om fx et alvorligt emne.

Der er imidlertid ikke meget, der støtter eleven $\mathrm{i}$ at se sammenhænge mellem valg af forskellige sproglige og semiotiske ressourcer og formål med talen. Eleven introduceres til faglige elementer inden for mundtlighed, men spørgsmålet er, om eleven får mulighed for at arbejde tilstrækkeligt dybdegående med det faglige indhold til at forstå og lære det, der er målet. Der er risiko for, at aktiviteten ikke lærer eleven hensigtsmæssig brug af kropssprog og stemme i mundtlig fremlæggelse og ej heller lærer eleven om talerens virkemidler på forskellige niveauer.

Den sidste af de tre aktiviteter hedder "Episke og lyriske digte" (Jensen, u.å.). Af lærerguiden fremgår, at aktiviteten egentligt forudsætter, at eleverne har arbejdet med teksterne "Bryllup" og "Der bor en ung pige". Læringsmålet knytter an til færdighedsmålet: "Eleven kan udtrykke en æstetisk teksts stemning" og vidensmålet "Eleven har viden om måder at udtrykke teksters stemning på" (Undervisningsministeriet, 2019, s. 14). I læremidlet omsættes disse til "Jeg kan argumentere for min vurdering af en tekst" (Jensen, u.å.e). Aktiviteten består i, at eleverne skal lave en diskussionscirkel med spørgsmålene: 
— Hvilken form for digte kan du bedst lide? Episke eller lyriske digte?

— Hvad er din vurdering af digtet "Bryllup" af Naja Marie Aidt?

— Hvad er din vurdering af digtet "Der bor en ung pige" af Tove Ditlevsen?

- Husk at argumentere for dit synspunkt og din vurdering af teksterne.

Diskussionscirklen beskrives andetsteds i læremidlet som en metode, hvor eleverne deles i to cirkler, stilles over for hinanden og "diskuterer løs med den, som du står over for, indtil tiden er gået" (Nielsen \& Danø, u.å).

Aktiviteten lægger op til, at eleverne diskuterer og argumenterer for egne synspunkter, men der er ingen eksplicit undervisning i, hvordan man diskuterer eller opbygger argumenter. Det betyder, at sammenhængen mellem, hvad man vil argumentere for, hvordan og hvorfor, er utydelig. Der er ingen støtte til, hvordan man opbygger en argumenterende tekst, hvilket ordforråd, der kunne anvendes i en argumentation for en personlig vurdering eller undervisning i betydningen af kropssprog, gestik og mimik i en diskussion. Der er heller ikke fokus på, hvordan man aktivt lytter i en diskussion. Endelig kan man diskutere, om det at argumentere for, hvilken form for digt man bedst kan lide, støtter eleven i at kunne udtrykke en æstetisk teksts stemning? Aktiviteten støtter ikke eleven i at opleve eller udforske teksternes stemninger eller at give udtryk for disse stemninger. Samlet set er aktiviteten snarere udtryk for undervisning med mundtlighed end undervisning $i$ mundtlighed.

For alle tre aktiviteter gælder, at læremiddelteksterne, der introducerer eleverne til det faglige emne, er meget korte. Der anvendes fagsprog i teksterne, og eleverne får dermed mulighed for at tilegne sig fagets diskurs - og dermed skolens sekundær-diskurs. Udfordringen er aktiviteternes løsrevne og begrænsede omfang. Aktiviteterne lægger op til elevernes selvstændige arbejde, men der er ingen modeltekster, og læremidlet viser ikke eksplicit, hvordan noget er eller gøres. Pga. portalens moduliserede organisering er der heller ingen eksplicit forbindelse til noget, eleven allerede har arbejdet med eller til elevens hverdagsliv. Der er derfor risiko for, at aktiviteterne kommer til at fremstå som løsrevne fragmenter, der vanskeliggør dybdelæring. 


\section{ii. Mundtlige tekster}

Som nævnt er der tale om en omfangsrig portal, så eksemplerne på, hvilke mundtlige tekster, der gøres til genstand for undervisning, er fremkommet gennem portalens søgefunktion. En søgning på "mundtlighed" resulterer i 17 tekster og 86 e-tekster. De 86 e-tekster er alle æstetiske tekster, fx Grundtvigs salme "Morgenstund har guld i mund" og kapitel 1-4 af "Guldregn" af Anders Bodelsen. Teksterne er alle skriftlige, verbalsproglige tekster. Via portalens oplæsningsfunktion kan de læses højt, men det er svært at se, hvorfor teksterne skulle være særligt "mundtlige". Ved at surfe rundt på portalen findes eksempler på forskellige mundtlige tekster - både tekster eleverne skal recipiere, og tekster eleverne skal producere, fx en mundtlig beretning om Loch Ness-uhyret, hvor eleverne får at vide, at de skal tænke på pauser og stemmeføring (Roslev, u.å.). Eleverne opfordres til at anvende stikord og tegninger til at støtte deres hukommelse, når de skal øve sig i at berette uden at læse op - et eksempel på undervisning i udvikling af kognitive hukommelsesstrategier. Som nævnt ovenstående viser norske undersøgelser, at når der arbejdes med mundtlige færdigheder, er det i høj grad elevfremlæggelser, der dominerer. At eleverne skal fremføre en mundtlig beretning, holde et oplæg eller fortælle en historie er typiske eksempler på sådanne elevfremlæggelser. I læremidlet er en række eksempler på, at eleverne netop skal lave forskellige fremlæggelser.

I surfingen fandtes også et forløb om performancelitteratur (Andersen, 2019). Formålet med forløbet er, at eleverne skal lære om performancelitteratur som genre, men forløbet består af en række forskellige mindre aktiviteter, hvoraf flere af dem har selvstændige læringsmål. I en delaktivitet skal eleverne lære at bruge en række analyseværktøjer til analyse af poetry slam-performance; i en anden delaktivitet skal eleverne lære at bruge kropssprog i fortolkningen af en tekst og kunne forklare forskellen mellem mundtlig og skriftlig litteratur. I nogle af delaktiviteterne skal eleverne eksperimentere med at lægge krop og stemme til uddrag af forskellige tekster. Og i nogle af aktiviteterne får eleverne støtte til, hvordan de kan eksperimentere med deres fremførelser, fx hvordan de kan bruge kroppen ("Lav store bevægelser, imens tekststykket læses op") eller stemmen ("Vælg, om du vil lægge særlig vægt på bestemte ord, og hvordan du vil gøre det (fx hviske ordet, råbe ordet, udtale det overdrevet tydeligt"). Aktiviteterne sætter fokus på de lokale niveauer i mundtlighedstrekanten 
som krop, gestik og tempo, men flere steder med opfølgningsspørgsmål om, hvad det betyder for oplevelsen af teksten. Fx skal eleverne læse sætningen "Det er dejligt vejr i dag, synes jeg" højt på forskellige måder, fx ved at lægge tryk på ét bestemt ord, gøre stemmen lys eller mørk eller tale højt eller lavt. Øvelsen afsluttes med opfordringen: "Tal til sidst sammen om, hvad variationerne gjorde ved sætningen”. Sådanne spørgsmål forbinder analysen med betydning og integrerer dermed arbejdet med trekantens lokale og globale niveauer.

I performancelitteratur-forløbet er også en række eksempler på, at eleverne skal se forskellige performances, fx Emil Nygaard ved poetry slam-mesterskaber i 2014 og MC Clemens med rap-nummeret "Regnskabets time". Men eleverne undersøger ikke teksterne som performance eller mundtligt sprog; i stedet skal eleverne anvende deres tilegnede viden om, hvad der karakteriserer performancelitteratur til skriftligt at karakterisere teksternes genre, fx "Skriv herunder, hvad der kendetegner rap" og derefter "Skriv, hvorfor MC Clemens "Regnskabets Time" er rap. Men performancelitteratur er netop kendetegnet ved den forskel fra skriften, som de performative aspekter tilføjer. Hvad gør fremførelsen af teksten ved publikum og dermed ved læseren, lytteren, tilskueren? Det er de performative elementer, der gør performancelitteraturen til noget særligt. Hvordan virker performancelitteraturen på os? Hvad virker? Hvordan kan man behandle performancelitteraturen som både skriftsprog og mundtlighed eller som en hybrid?

Performancelitteratur er en måde at gøre og opleve litteratur på, som inddrager kroppen, rummet, stemmen og synet. De mange små opgaver i forløbet, der til dels antager selvstændig karakter med fx egne læringsmål, betyder, at læreren skal gøre et stykke arbejde for at samle de forskellige elementer på en måde, så både trekantens niveauer og hjørner sættes i spil.

\section{iii. Mundtlighed som tema}

Som nævnt i karakteristikken af læremidlet findes under kategorien "Emner" og "Sprog" temaet "Mundtlighed". Alle emner har en ensartet opbygning inddelt i tre dele: "Tekst", der er en introducerende og formidlende læremiddeltekst, "Aktiviteter", og "Inspiration", der er henvendt til læreren. Under "Mundtlighed" er en "Introduktion", der er ganske kort og alene handler om forskellen mellem talesprog og skriftsprog og derudover fem temaer. Temaerne "Foredrag", "Oplæsning” og "Den gode tale" 
er alle eksempler på undervisning i elevens fremførelse af en mundtlig tekst med særligt fokus på mundtlighedstrekantens lokale niveauer. I alle tre tilfælde må eleven selv bestemme, hvad der skal tales om eller læses op. Under temaet “Talesprog” skal eleverne gennemføre et interview - de vælger selv med hvem og om hvad. Ved at transskribere et selvvalgt minut af interviewet skal eleverne opdage forskelle og ligheder mellem tale-og skriftsprog (Billeskov, u.å.).

Temaet "Debat" er interessant at dykke ned i, fordi unders $\emptyset$ gelser viser, at læremidlerne især støtter læreren i at undervise eleverne i fremlæggelser. Samtidig fremhæves klassesamtale forskningsmæssigt som særligt relevant at arbejde med - både med henblik på elevernes dannelse til deltagelse i demokratiske processer og som stillads for elevernes læring (Høegh, 2018; Reznitskaya, 2012; Haugsted, 2000; Dysthe, 1997).

Debat-emnet er forfattet af Ditte Christiane Jensen (u.å.a) og åbnes således: "Du har sikkert hørt om politiske debatter i forbindelse med et Folketings- eller Kommunalvalg. En debat er en form for diskussion mellem forskellige mennesker, der er uenige om noget" (Jensen, u.å.a). Formuleringen tager på den ene side afsæt i elevernes erfaringsverden, på den anden side kan formuleringen virke ekskluderende på den elev, der ikke har "hørt om" politiske debatter. Der er forskel på at have hørt om en politisk debat og at have hørt en politisk debat. Formuleringen kommer til at fremstå som en svag klassifikation og rammesætning (Chouliaraki \& Bayer, 2001). Dvs. at den elev, der har hørt en politisk debat gennem påmindelsen får aktiveret en slags implicit modeltekst, mens den elev, der aldrig har hørt en politisk debat, ikke har noget at referere til og dermed ingen hverken implicit eller eksplicit modeltekst til at støtte arbejdet.

Eleverne skal lave en paneldiskussion ud fra et selvvalgt emne. Det skal de gøre ved 1. "Læs en artikel om emnet. (www. dr.dk)", og 2. "Find ud af, hvad artiklen mener om den aktuelle sag, der debatteres". Dernæst skal eleverne tale om, hvad de mener om sagen, og i grupper af fire elever vælge to elever, der er for et bestemt synspunkt, og to elever, der er imod. Debatten gennemføres, mens de øvrige elever skal spørge ind til og diskutere indholdet af oplæggene.

Man kan spørge, om dette er et eksempel på undervisning $i$ mundtlighed? Vises eleverne, hvordan man gør debat? Opgavestillingen vedrører mundtlighedstrekantens globale niveau, og kun på et meget generelt niveau. Genren gives, elever- 
ne skal lave en "paneldebat", men kommunikationssituationen indkredses ikke nærmere. Hvad er formålet med debatten? Hvem skal eleverne overbevise og i hvilken forestillet kontekst? Og hvordan gør man det? Eleverne støttes kun gennem et sæt overordnede "spilleregler". Der er ingen undervisning i, hvordan sproglige formuleringer, krop, gestik og mimik kan understøtte debatdeltageren. Elevernes frie valg af alle emner kan umiddelbart fremstå motiverende, men det betyder samtidig, at det er vanskeligt at undervise eleverne eksplicit i semantiske netværk og opbygning af relevant ordforråd. Både ord og begreber, der knytter sig til emnet, og ord og begreber, der anvendes i en debat og som er karakteristiske for genren.

Med forståelsen af danskfaget som kommunikationsfag og med vægt på autentisk kommunikation, kunne man have forventet, at eleverne skulle debattere en sag, som er væsentlig for dem, og som de kunne debattere med reelle modtagere enten inden for eller uden for skolen. Alle "Emner" fremstår som løsrevne aktiviteter, der kan gennemføres på typisk 90 minutter. Det er lærerens opgave at integrere undervisningen med den øvrige danskundervisning - ellers risikerer undervisningen at ende i en instrumentalisering af faget, hvor eleverne undervises i løsrevne elementer af faget.

\section{Vurdering}

Udgangspunkt for analysen af læremidlet var spørgsmålet om, i hvilken udstrækning det støtter læreren $\mathrm{i}$ at undervise $i$ mundtlighed. Vurderingen er både en vurdering afy, i hvilken udstrækning teoretisk danskdidaktisk viden om undervisning i mundtlighed omsættes i læremidlet, men også en vurdering af, om der er sammenhæng mellem det, læremidlet siger (om danskfaget og om mundtlighedsundervisning) og det, der faktisk sker i læremidlet, og om der er sammenhæng med læreplanen. Som beskrevet fortolkes danskfaget som et kommunikationsfag, hvor eleverne skal opleve at indgå i autentiske kommunikationssituationer. Det fremhæves ligeledes, at netop digitale læremidler giver særligt gode muligheder for at sprænge skolens traditionelle rammer og kommunikere med verden. De analytiske nedslag i læremidlet viser, at de forskellige aktiviteter og emner sætter fokus på både globale og lokale dele af mundtlighedstrekanten, men også, at disse ikke altid integreres på en måde, så eleven får mulighed for at udforske sammenhængen mellem niveauerne.

Når læremidlet lægger op til, at eleverne skal diskutere 
og argumentere, (om)skrive og fremføre (et uddrag af) en lejlighedstale eller gennemføre en debat uden egentlig eksplicit undervisning heri, er risikoen, at elever fra literacy-stærke hjem favoriseres (Blikstad-Balas, 2016). 1970'ernes klasserumsobservationer satte kritisk blik på en lærerstyret undervisning (Haugsted, 2000, s. 259; Høegh, 2018, s. 27) - men Tina Høegh argumenterer for, at den lærerstyrede samtale er god til at vise eleverne, hvordan man tænker i faget (Høegh, 2017, s. 109). Udfordringen anno 2020 synes at være, at læreren - og læremidlerne - ikke anvender tilstrækkeligt fagsprog og ikke i tilstrækkelig grad viser hvordan. Det er ikke nok, at eleverne skal diskutere eller argumentere, hvis ikke de vises hvordan. Lærerens - eller læremidlets - stilladsering og eksplicitte undervisning er afgørende for elevernes læringspotentiale (Dysthe, 1997, s. 31). Læremiddelanalysen kan ikke give svar på, hvad der faktisk sker i klasserummet, men analyserne peger på, at der er brug for klasserumsobservationer af undervisning med læremidlerne for at undersøge, hvad der karakteriserer denne.

Gennem tre analytiske nedslag i læremidlet vises, at der både undervises med og i mundtlighed. Men analyserne viser også, at der er tale om ganske korte og afgrænsede aktiviteter. En af udfordringerne er det digitale læremiddels moduliserede opbygning, hvor en aktivitet fx "genbruges" i forskellige sammenhænge og derfor får en mere selvstændig karakter, som kræver, at læreren forbinder denne med en større faglig fortælling. Når undervisning i mundtlighed foregår i mange små elementer, er der risiko for, at eleverne ikke får mulighed for at fordybe sig, arbejde udforskende og øve sig. von Oettingen skriver: "Øve og gentage. Som vi tidligere var inde på, er det at øve og gentage en grundlæggende læringsform i undervisningen. Læreren skal [...] variere det, der er blevet sagt, og efterspørge og kontrollere, om eleverne har forstået indholdet. At øve, gentage og variere er vigtige elementer og stilladser for elevernes læringsprocesser" (von Oettingen, 2016, s. 173). Når eleverne arbejder udforskende med tekster, skal de fx øve sig i at sætte mundtlighedstrekantens forskellige niveauer i et meningsfuldt forhold til hinanden. Dette står i modsætning til en undervisning, hvor eleverne i stedet blot sættes til at finde eksempler på fx genretræk i tekster eller bestemte virkemidler. I de tilfælde arbejder eleverne ikke udforskende med tekster, men "bruger" blot teksten som et middel til at give eksempler, fx på hvad der karakteriserer rap som genre.

Det betyder ikke, at eleven skal tilbydes en lang række løs- 
revne træningsopgaver, men må snarere forbindes med Wolfgang Klafkis forståelse af dannende læring, der:

99

[ikke] nås gennem reproduktiv overtagelse af den størst mulige mængde enkelterkendelser, -evner eller -færdigheder, men derimod ved at den lærende ud fra et begrænset antal udvalgte eksempler arbejder sig frem til aktivt almene, nærmere bestemt: mere eller mindre vidtrækkende almengyldige kundskaber, evner og holdninger, eller med andre ord: væsentlige, strukturelle, principielle, typiske, lovmæssige, omfattende sammenhænge.

(Klafki, 2001, s. 176)

Der er brug for mere sammenhængende forløb med undervisning i mundtlighed, hvor eleverne kan arbejde udforskende med mundtlige tekster på mange forskellige måder og niveauer - gerne med den samme tekst.

\section{Konklusion}

I danskundervisningen skal eleven lære at bruge de både sproglige og ikke-sproglige kommunikative ressourcer, eleven har til rådighed for at skabe betydning i forskellige situationer. Det er en vigtig pointe i vores projekt, at arbejdet med mundtlighedens forskellige kommunikative ressourcer bør ske i en integreret vekselvirkning, så undervisningen ikke kommer til at bestå af løsrevne sekvenser. Samtidig er det en vigtig pointe, at der i danskfaget er fokus på danskrelevante indholdsområder, således at det ikke kun handler om at "sige noget", men også "hvad taler vi om" (jf. Høegh, 2018). Det vil sige, at hvis vi skal tilbyde eleverne relevante måder at bruge det mundtlige sprog på, må vi ikke alene sikre situationer, hvor eleverne kan vælge mellem flere måder at skabe betydning på med verbalsprog (Kabel, 2017), men også sikre, at disse situationer er fagligt relevante - dvs. er mundtlighed om noget væsentligt danskfagligt. Samtidig er det vigtigt at sikre, at eleverne møder skolens sekundærdiskurs - både når det gælder danskfagets indhold og form.

Begge de analyserede læremidler sætter fokus på danskfagets traditionelle mundtlige områder, fx oplæsning, fortælling, fremlæggelse og debat. Dette er områder, som mange læremidler i forvejen understøtter. Med udgangspunkt i nyere mundtlig- 
hedsforskning kunne man ønske et læremiddel med fokus på klassesamtalen og mere kritiske, undersøgende samtaler, hvilket ville være oplagt, at netop et temabaseret læremiddel i mundtlighed kunne omfatte. Lærerne og eleverne tilbydes ikke i de analytiske nedslag redskaber til at indgå i mere eksplorative og kritiske samtaleformer. Ordet er dit, som netop er et temabaseret læremiddel til direkte undervisning $i$ mundtlighed, tilbyder ikke et nyt perspektiv på mundtlighed, som fx danskfaget.dk ikke også omhandler. Læremidlet har dog eksplicit fokus på lytning som en vigtig del af mundtligheden. Når mundtlighedstrekanten fungerer som analytisk greb i læremiddelanalysen, synliggøres det, hvad en elementarisering af de enkelte områder betyder. Når læremidlerne ikke arbejder helhedsorienteret og ikke integrerer de enkelte dele i mundtlighedstrekanten, er der risiko for, at eleverne ikke erkender samspillet mellem, hvem siger hvad til hvem, hvordan, hvorfor og i hvilken situation.

Mundtlighedstrekanten kan også fungere som et redskab til læreren i forhold til at planlægge, gennemføre og evaluere undervisning i mundtlighed med det formål at sikre en integreret mundtlighedsdidaktik, der tilgodeser både kognitive og sociokulturelle perspektiver og som sikrer at indhold, formål og form går hånd i hånd. Samtidig bidrager trekanten med et relevant metasprog til både lærere og elever, så det netop sikres, at skolens sekundærdiskurs fastholdes.

Klassesamtalen har både i et almendidaktisk og et fagdidaktisk perspektiv særlige potentialer. Udvikling af elevernes mundtlige sprog gennem både deltagelse i og eksplicit undervisning i klassesamtalen, støtter ikke blot elevernes mulighed for deltagelse i skolens literacy-kontekster (mundtlighed som læringsredskab og analyseredskab), men rækker gennem sit dannelsespotentiale ud over skolen, idet eleven gennem klasserumsamtalen lærer at udtrykke sig selv samtidigt med, at eleven lærer at indtage den anden eller de andres perspektiv, hvormed eleven har mulighed for at blive klogere på sig selv og "verden". Dette sker ikke af sig selv, men ved at læreren - og læremidlerne underviser eksplicit i mundtlighed.

\section{Referencer}

Adelmann, K. (2012): The art of Listening in an Educational Perspective. Listening reception in the morther tongue. Education Inquiry, 3(4), 513-534. Aknes, L. M. (2016). Om muntlighet som fagfelt. I: K. Kverndokken, K. (red.), 101 måter å fremme muntlige ferdigheter på. Bergen: Fagbokforlaget. 
Andersen, M.M. (u.å.). Performancelitteratur. Tilgået den 18. december 2019 på: danskfaget.dk.

Blikstad-Balas, M. (2016). Skolens nye literacy: Hvordan endres skolens tekstpraksiser når digital teknologi er tilgjengelig i klasserommet? Learning Tech: Tidsskrift for loeremidler, didaktik og teknologi, (1), 77-98.

Blikstad-Balas, M. (2019): Literacy i skolen. Universitetsforlaget.

Billeskov, A. (u.å.). Talesprog. Tilgået den 18. december 2019 på: danskfaget. dk. https://portals.clio.me/dk/dansk/4-6/emner/sprog/mundtlighed/ talesprog/

Bundsgaard, J. (2008). Søgning er læsning. Viden om loesning, (3), 5-10.

Bundsgaard, J. (2017). Digital dannelse. Aarhus: Aarhus Universitetsforlag. Pædagogisk Rækkevidde.

Bundsgaard, J., Buch, B. \& Bremholm, J. (2017). De anvendte læremidlers danskfag belyst kvantitativt. I: J. Bremholm, J. Bundsgaard, S. Fougt, S. \& A. K. Skyggebjerg (red.), Loeremidlernes danskfag. Aarhus: Aarhus Universitetsforlag.

Carlsen, D. \& Ipsen, M. (2019). Mundtligheden er der jo bare! I: A. v. Oettingen \& K. Thorgård (red.), Universitetsskolen: mellem forskning, uddannelse og skoleudvikling (s. 123-136, Undervisning og læring). Frederikshavn: Dafolo.

Chouliaraki, L. \& Bayer, M. (2001). Basil Bernstein - pædagogik, diskurs og magt. København: Akademisk Forlag.

danskfaget.dk, 4.-6. klasse. (https://portals.clio.me/dk/dansk/4-6/).

Dysthe, O. (1997). Det flerstemmige klasserum. Skrivning og samtale for loering. Aarhus: Klim.

Dysthe, O., Hertberg, F. \& Hoel, T.L. (2001). Skrive for at loere. Aarhus: Klim Elf, N. (2017). Medier, tekst og tegn i dansk. I: E. Krogh, N. F. Elf, T. Høegh \& H. Rørbech, Fagdidaktik i dansk. Frederiksberg: Frydenlund Academic.

EVA. (2012). Foelles Mål i Folkeskolen. Danmarks Evalueringsinstitut.

Finnemann, N. O. (2005). Internettet i mediehistorisk perspektiv. København: Samfundslitteratur.

Gee, J. P. (u.å.). Literacy og diskurs. Literacy.dk, Nationalt Videncenter for Læsning (https://literacy.dk/media/1029/literacy-og-diskurs-kerneartikelopdateret-1.pdf).

Gilje, Ø. (2015). På jakt etter ark og app i fire fag i det nye norske læremiddellandskapet. Learning Tech - Tidsskrift for loeremidler, didaktik og teknologi, (1), 36-61.

Gilje, Ø., Ingulfsen, L., Dolonen, J. A., Furberg, A., Rasmussen, I., Kluge, A., Knain, E., Mørch, A., Naalsund, M. \& Skarpas, K. G. (2016). Med ARK\&APP. Bruk av loeremidler og ressurser for loering på tvers av arbeidsformer. Oslo: Reprosentralen, Universitetet i Oslo.

Hansen, T. I. (2012). Indhold og genstand. I: S. T. Graf, J. J. Hansen \& T. I. Hansen (red.), Loeremidler i didaktikken - didaktikken i loeremidler. Aarhus: Klim.

Hansen, T. I. (2015). Dansk (i serien Mål og midler). Aarhus: Klim.

Hansen, T. I. \& Bundsgaard, J. (2013). Kvaliteter ved digitale loeremidler og ved pcedagogiske praksisser med digitale loeremidler: forskningsbaseret bidrag til anbefalinger, pejlermoerker og kriterier iforbindelse med udmøntning af midler til indkøb af digitale loeremidler (rapport). Ministeriet for Børn og Undervisning (http://uvm.dk/Uddannelser-og-dagtilbud/Folkeskolen/Ifokus/Oeget-anvendelse-af-it-i-folkeskolen/Evaluering-af-effekten-afdigitale-laeremidler). 
Hansen, T. I. \& Bundsgaard, J. (2011). Evaluation of learning materials: A holistic framework. Journal of Learning Design, 4(4), 31-44. https://www.jld. edu.au/article/view/87

Hansen, T. I. \& Skovmand, K. (2011): Foelles mål og midler. Loeremidler og loereplaner i teori og praksis (i serien Mål og midler). Aarhus: Klim.

Haugsted, M. (1999). Handlende mundtlighed: Mundtlig metode og cestetiske loereprocesser (i serien Dialog. Sprogpædagogisk Skriftserie). København: Danmarks Lærerhøjskole.

Haugsted, M. (2000). Talte tekster - mundtlighed og undervisning. I: K. Esmann, A. Rasmussen \& L. B. Weise, Dansk i dialog (s. 257-288). Frederiksberg: Dansklærerforeningens Forlag.

Hodgson, J., Rønning, W., Skogvold, A. S. \& Tomlinson, P. (2010). Paa veifra laereplan til klasserom - Om laereres fortolkning, planlegging og syn paa LKo6. Bodø: Nordland Research Institute.

Hvass, H. (2017). 4.10. Mundtlighed. I: J. Dolin, G. H. Ingerslev \& H. S. Jørgensen, Gymnasiepcedagogik. En grundbog. København: Hans Reitzels Forlag.

Høegh, T. (2017). Mundtlighed og mundtlige tekster i danskfaget. I: E. Krogh, N. F. Elf, T. Høegh \& H. Rørbech, Fagdidaktik i dansk. Frydenlund.

Høegh, T. (2018). Mundtlighed og fagdidaktik. København: Akademisk Forlag.

Høegh, T. (2020): Lytning - mere end den halve dialog. I: O. Dysthe, P. O. Kierkegaard \& I. J. Ness (red.), Dialogisk poedagogik, kreativitet og loering. Aarhus: Klim.

Jensen, D. C. (u.å.a). Debat. Tilgået på danskfaget.dk, https://portals.clio.me/ $\mathrm{dk} /$ dansk/4-6/emner/sprog/mundtlighed/debat/?keeplang=1 (18.12.19)

Jensen, D. C. (u.å.b). Om portalen. Tilgået på danskfaget.dk, https://portals. clio.me/dk/dansk/4-6/om-portalen/?keeplang=1 (6.4.20)

Jensen, D. C. (u.å.c). Det offentlige privatliv. Tilgået på danskfaget.dk, https:// portals.clio.me/dk/dansk/4-6/emner/medier/web/offentligt-privatliv/detoffentlige-privatliv/?keeplang $=1$ (6.4.20)

Jensen, D. C. (u.å.d). Dronningens nytårstale. Tilgået på danskfaget.dk, https:// portals.clio.me/dk/dansk/4-6/emner/sprog/mundtlighed/den-gode-tale/ dronningens-nytaarstale/?keeplang=1 (6.4.20)

Jensen, D. C. (u.å.e). Episke og lyriske digte. Tilgået på danskfaget.dk, https:// portals.clio.me/dk/dansk/4-6/emner/skoenlitteratur/lyriske-tekster/enlyrisk-tekst/episke-og-lyriske-digte/?keeplang=1 (6.4.20)

Kabel, K. (2017). Fagspecifik literacy: Når elever skaber betydning,. I: S. K. Knudsen \& L. Wulff (red.), Kom ind i sproget (s. 87-104). København: Didaktikserien, Akademisk Forlag.

Kirkegaard, P. O. (2018). Mundtlighed og dialog som en didaktisk opmærksomhed. Didaktisk opmoerksomhed - kollegial refleksion. Kognition og poedagogik. Tidskrift om gode loeringsmiljøer, 28(108).

Klafki, W. (2001). Dannelsesteori og didaktik - Nye studier. Aarhus: Klim.

Madsen, P. H. (2017). Ordet er dit. Fokus på mundtlighed i 5.-6. klasse. Dansklærerforeningens Forlag.

Nationalt Videncenter for Læsning. (2012). Tema: Literacy. Tidsskriftet Viden om Loesning, (12).

Nielsen, A. P. \& Danø, M. (u.å.). Diskussionscirkler. Tilgået på danskfaget.dk (6.4.20)

Ongstad, S. (2004). Språk, kommunikasjon og didaktikk. Norsk som flerfaglig og fagdidaktisk ressurs. Bergen: Fagbokforlaget/LNU. 
Otnes, H. (2016). Lyttehandlinger og lytteformål - perspektiver på lyttedimensjonen i ulike fagplaner og kontekster. I: K. Kverndokken (red.), 101 måter å fremme muntlige ferdigheter på-om mundtlig kompetanse og muntlighetsdidaktikk. Bergen: Fagbokforlaget.

Reznitskaya, A. (2012). Dialogic teaching: Rethinking Language Use during Literature Discussions. The Reading Teacher, 65(7), 446-456.

Roslev, M. (u.å.) Loch Ness-uhyret. Myter og sagn. Tilgået på danskfaget.dk (6.4.20)

Skjelbred, D. (2019). Skolens tekster - et utgangspunkt for loering. Oslo: Cappelen Damm Akademisk.

Skov, L. I. (2018): At lytte for at lære - et deltagerorienteret perspektiv på lytning i skolen. Viden om literacy, (23).

Svenkerud, S. (2013): Ikke stå som en slapp potet - elevsynspunkter på opplæring i muntlige ferdigheter. Acte Didactica, $7(1)$.

Togeby, O. (2014). Bland blot genrerne - ikke tekstarterne! Om sprog, tekster og samfund. København: Samfundslitteratur.

Undervisningsministeriet. (2019). Dansk. Faghæfte 2019. Hentet fra: https:// emu.dk/sites/default/files/2020-o6/GSK_Dansk_Fagh\%C3\%A6fte_2020.pdf von Oettingen, A. (2016). Almen didaktik - mellem normativitet og evidens.

København: Hans Reitzels Forlag. 


\section{Learning Tech - Tidsskrift for læremidler, didaktik og teknologi Udgives af Læremiddel.dk}

Learning Tech er et forskningstidsskrift, hvor alle artikler er forskerbedømt i form af dobbeltblindt peer review. Tidsskriftet bringer artikler, der rammer genstandsfeltet mellem læremidler, didaktik og teknologi, og hensigten er at spille en betydelig rolle som platform for den voksende skandinaviske læremiddelforskning.

\section{Redaktion}

Stig Toke Gissel, UCL Erhvervsakademi og Professionshøjskole (ansvarshavende redaktør)

Bettina Buch, Professionshøjskolen Absalon

Hildegunn Juulsgaard Johannesen, University College Syd

Ove Christensen, Professionshøjskolen Absalon

René Boyer Christiansen, Professionshøjskolen Absalon

Thomas R.S. Albrechtsen, University College Syd

\section{Redaktionssekretær}

Trine Ellegaard, UCL Erhvervsakademi og Professionshøjskole

\section{Temaredaktion}

Stig Toke Gissel, UCL Erhvervsakademi og Professionshøjskole Thomas R.S. Albrechtsen, University College Syd

\section{Design og grafisk tilrettelæggelse}

Trefold - grafisk design og kommunikation

\section{Tryk}

Narayana Press, Gylling

ISSN 2445-7981 (Tryk)

ISSN 24.45-6810 (Online)

\section{Rettigheder}

(C) 2020 Læremiddel.dk og forfatterne

\section{Kontakt}

Læremiddel.dk, Niels Bohrs Allé 1, 5230 Odense M www.laeremiddel.dk

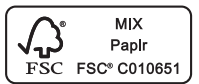

